University of Nebraska - Lincoln

DigitalCommons@University of Nebraska - Lincoln

Faculty Publications, UNL Libraries

Libraries at University of Nebraska-Lincoln

2012

\title{
Inciting Curiosity and Creating Meaning: Teaching Information Evaluation through the Lens of "Bad Science"
}

Catherine Fraser Riehle

Purdue University, catherine.riehle@unl.edu

Follow this and additional works at: https://digitalcommons.unl.edu/libraryscience

Part of the Information Literacy Commons

Riehle, Catherine Fraser, "Inciting Curiosity and Creating Meaning: Teaching Information Evaluation through the Lens of "Bad

Science"" (2012). Faculty Publications, UNL Libraries. 358.

https://digitalcommons.unl.edu/libraryscience/358

This Article is brought to you for free and open access by the Libraries at University of Nebraska-Lincoln at DigitalCommons@University of Nebraska - Lincoln. It has been accepted for inclusion in Faculty Publications, UNL Libraries by an authorized administrator of DigitalCommons@University of Nebraska - Lincoln. 


\title{
Inciting Curiosity and Creating Meaning: Teaching Information Evaluation through the Lens of "Bad Science"
}

\author{
Catherine Fraser Riehle \\ Purdue University Libraries, West Lafayette, Indiana, USA \\ Corresponding author - Catherine Fraser Riehle, Purdue University Libraries-HSSE, 504 W. State St., West Lafayette, \\ Indiana 47907-2058, email cfriehle@purdue.edu
}

\begin{abstract}
Ability to evaluate information is a critical component of information literacy. This article provides strategies for engaging students in learning about information evaluation in the contexts of the scientific publication cycle and communication in the digital age. Also included are recent findings regarding undergraduate student research behavior and ideas for integrating constructivist learning theory in order to develop effective learning activities that encourage curiosity and critical thinking.
\end{abstract}

Keywords: constructivist learning theory, information evaluation, information literacy instruction, undergraduate students

\section{Introduction}

Educators in higher education often lament their students' subpar research citations and relatively low usage of information sources that require more than a simple Google search to find. Several studies examining undergraduate student citation behavior confirm such anecdotes, citing prominent reliance on free and "nonscholarly" web sources (Currie, Delvier, Emde, \& Graves, 2010; Davis, 2002; Griffiths \& Brophy, 2005; Grimes \& Boening, 2001; Van Scoyoc \& Cason, 2006). A Project Information Literacy (PIL) study that surveyed more than 8,000 college students from 25 U.S. campuses reported that students consider themselves adept at evaluating information and that they regularly do so for personal and 
academic use. Respondents claimed to apply evaluation criteria such as currency, author credentials, URL, and interface design (Head \& Eisenberg, 2010). Do these findings contradict anecdotal and other research-based reports? If students report they evaluate information based on standard evaluation criteria, why is there little evidence in the majority of citation analyses of their work?

In some cases, the answer to these questions may be a lack of clear communication and instruction regarding expectations and standards for "scholarly" and "quality" sources or possibly insufficient knowledge about how to find them. Head and Eisenberg's (2010) findings may suggest another answer. Students rely on established routines for completing their research assignments, and many of those routines are the same as those used in high school when research expectations may have been different. When researching and selecting tools and search engines to use, students prioritize effectiveness (relevant results), efficiency, and ease of use (Burton \& Chadwick, 2000; Grimes \& Boening, 2001; Johnson, Griffiths, \& Hartley, 2003), and they return to many of the same sources and search engines, relying on what is readily available. These include course readings, search engines (including Google), and some scholarly research databases (Head \& Eisenberg, 2010). That evaluative criteria including currency, credentials, and URL, rise to the top for PIL respondents may reveal a black-and-white "check-list mentality" conveyed in the way information evaluation is taught. Where, in the process of checking these criteria, is the need for critical thinking and for inquiry, both necessary components of the research process? By teaching information evaluation in the context of "evaluating websites" and as a procedure by which one merely notes whether or not a resource satisfies specific criteria, instructors neglect an opportunity to delve into broader and more critical information literacy concepts related to information evaluation. If students rely on what is easy and familiar, how can we motivate them to invest more time and more thought into finding and evaluating sources? By changing the way we teach information evaluation, can we improve students' information use and broaden their thinking about information in the digital age?

\section{An Ineffective Approach}

As an instruction and liaison librarian at a large research university, I frequently cover information evaluation as part of one-time instructional sessions and workshops. As coinstructor of a one-credit, year-long, first-year honors seminar, I began each academic year poised to improve my students' information evaluation skills and consequently, the quality of their bibliographies. My approach was presented in the context of "evaluating websites." First, I asked students to brainstorm in groups criteria for evaluating websites; they shared their criteria with the class as a whole, and I filled in gaps by reviewing traditional information evaluation criteria (e.g., accuracy, authority, currency, objectivity, and coverage). I then assigned a variety of websites (some credible, some not) relevant to the course subject matter and asked them to summarize an evaluation for each, armed with a handout listing the criteria. Most completed this assignment successfully and were able to discern quality sites from subquality sites. 
I would have considered this learning activity a success had I not sensed boredom radiating from most of the students in my class, and had they transferred the evaluation skills they possessed to their research assignments later in the semester. The students were not engaged in an activity on evaluating websites; many reported anecdotally and later in course evaluations that they had participated in similar exercises before in other classes on campus or before college. They seemed even insulted to be presented in an honors seminar a concept they perceived as remedial. Regardless, when assigned that semester to reference only scholarly, authoritative sources for their research projects and assignments, they cited Wisegeek.com, popular magazine articles, and opinion pieces from student newspapers. Their ability to recite and apply standard evaluation criteria to websites did not transfer to a research assignment. This realization inspired pedagogical transformation.

\section{Constructivist-Inspired Transformation: Beyond "How To"}

Participation in the Teacher Track of the Association of College and Research Libraries' (ACRL) Immersion Program, an intensive information literacy professional development program for teacher-librarians, exposed me to theories in teaching and learning that brought about critical reflection regarding my own teaching. I was inspired especially by the tenets of constructivist learning theory, which place problem-solving along with construction of personal meaning, at the heart of learning. Learning, according to constructivist theorists, is "an active process that requires change in the learner ... achieved through the activities the learner engages in ... and through reflection" (Lamon, 2003, p. 1463). In constructivist learning environments, the role of the instructor is not to impart knowledge but to facilitate dialogue, to prompt, and to challenge. Learning is an active process that requires understanding beyond the mastery of particular skills. It was clear to me that focusing my teaching on "how to evaluate websites" was not benefitting the students or enabling them to construct new or personal knowledge about the digital information age in which we live.

In a thought-provoking article that calls for emphasis on creativity and curiosity in information literacy instruction, Hensley (2004) reminds readers that information literacy is about navigating a complex digital world and about inquiry and critical thinking, not only about how to find, use, and evaluate information. To encourage inquiry and critical thinking, the "why" is of utmost importance in information literacy instruction. According to Hensley:

At its most fundamental level, the exploration of why there is information, why a person should care, and what meaning information has for the individual not only engages the seeker in the deeper and personal aspects of living in the world of information and meaning but also encourages the very qualities that provide dynamic involvement in that world: curiosity and creativity. (p. 35)

To achieve this, a learning environment should be rich in inquiry, not dominated by procedure, which I had reiterated by presenting my students with a checklist of evaluation criteria. Learning activities should allow students to experience the problematic nature of information use and evaluation, which I had avoided by preselecting topics and websites 
to evaluate. Inspired by these ideas, I developed a new approach for teaching information evaluation the following semester.

\section{A New Approach}

Learning outcomes related to information evaluation were established to guide planning and assessment. Previously, students were expected to apply information evaluation criteria in order to evaluate websites for research. Revised learning outcomes expanded application beyond websites and the evaluation process beyond academic research.

\section{Revised Learning Outcomes}

Students should be able to:

- explain the scholarly publication and communication cycle in order to grasp the complexity of information in the digital information age;

- evaluate information sources in order to select authoritative and appropriate sources for research assignments; and

- articulate how this knowledge and these skills can be applied to other areas of their academic and personal lives in order to make meaning and personal context.

Before any content about information evaluation or scholarly communication was presented, students were asked to spend time perusing Ben Goldacre's "Bad Science" column in the online version of The Guardian. In the weekly column and blog by the same name, best-selling author, broadcaster, and medical doctor Goldacre picks apart faulty scientific claims and studies, unveiling flaws in research methodology and pointing fingers at poor science communication. "Bad Science" headlines such as "The true purpose of a drug trial is not always obvious," "How far should we trust health reporting?," and "The deeper the data set, the more it can tell you," are representative examples of the types of studies and reports on which Goldacre focuses. Students were assigned to read a few examples of their choice from the column and to post a brief reflection on the course blog. For their reflections, students were asked to include a general response to what they read and an explanation of how they evaluate what they read for school and for "everyday life."

After perusing "Bad Science" and posting reflections, the following class period began with a discussion about what the students read and posted to the class blog, including studies they had referenced, surprising realizations, and conclusions. Students' reflections were projected visually in a word cloud format to highlight trends. This discussion served as an introduction to presentation and dialogue on the scientific publication cycle, which featured University of North Carolina's (UNC) Biology Research Tutorial graphic as a starting point. UNC's model includes writing, submission, review, revisions, publication, indexing, and sharing. Instructors also shared personal anecdotes about the peer-review and publication processes. Popular media venues such as news sites, personal websites such as blogs, and social networking tools such as Facebook and Twitter were added to UNC's visualization to demonstrate the impact of the publication cycle beyond peer-reviewed 
literature. This provided an opportunity for discussion about how these venues and methods for communication differ and relate. The presentation and discussion, especially in contrast to previous semesters' on "evaluating websites," encouraged students to consider the complicated information world in which they live. "Why we should care" was explored in this broader, real-life context.

Class concluded with two brief, interactive activities borrowed from examples in Darrell Huff's (1954) classic text How to Lie with Statistics. A hands-on activity demonstrating the importance of appropriate sample size with pennies and an exercise critiquing graphs printed in online news sources that presented the same data in different, dubious ways, encouraged students to think more deeply about how research is conducted and how findings are represented and interpreted. These active learning opportunities fostered individual and group problem-solving and engaged students in specific, real-life implications of evaluating and presenting arguments and data.

\section{Outcomes and Reflections}

This new approach to teaching information evaluation required students to inquire and to think critically. Reflections posted on the course blog (excerpts below) demonstrate students' engagement with "Bad Science" content and their grasp of key learning outcomes.

\section{Selected Excerpts from Student Reflections}

- "Basically, after reading a few of these I have a new appreciation for determining the reliability of a source. Clearly, even things in stipulated [sic] journals and magazines can have credibility issues and authors with titles are constantly manipulating readers. I am going to be much more wary when doing research in the future."

- "It makes me really think about all of the research and articles I have heard about. ... I will definitely pay closer attention to the sources and credibility of my future research. I would like to learn more on how to judge the reliability of science and articles I read."

- "I felt that these articles really made me think about what is the truth in science and what isn't. . . . After reading the articles my outlook on science has changed and I am not as sure about the reliability of science as I was before."

- "Before reading these articles I believe that I was pretty aware of the effects of media portraying information in a biased or unproportional [sic] way. ... I do not really ever research anything, but in the future I will have to make sure I am citing credible resources."

- "I find it amazing how the presentation of data can actually change how people interpret data. It makes me realize that perception is often reality. After reading many of the articles I found that credibility is an extremely important 
part of how I need to pick my research. I not only need to look at the credibility of the research and how it is conducted, but I also need to look at the integrity of how the research is presented."

Even before lecture and in-class discussion and activities, student reflections revealed achievement of some learning outcomes, particularly the establishment of personal context related to information evaluation and their greater understanding of the scientific and scholarly publication processes. Student responses indicated they were engaged in the subject matter and eager to learn how to more effectively evaluate information. Follow-up discussion and interactive activities related to the scientific publication and communication provided an effective background for exploring other learning outcome-related content. Through exploration of self-selected postings and through reflection, students developed their own questions and came to their own conclusions in the context of science, communication, and information resources in general.

Assessment in the form of reflective exercises (blog postings) for this learning activity revealed deeper learning occurred, as demonstrated by articulation of some key evaluation criteria as well as big-picture context surrounding the importance of information evaluation beyond evaluating websites, echoing established learning outcomes. Mini research assignments later in the semester (argument outlines and sources cited structured for inclass debates on course topics) reflected selection of higher quality and more appropriate sources overall than the previous semester, though a semester-to-semester comparison is not entirely valid since the research assignment changed.

It is worth noting that additional content, about how to frame and narrow research topics and access scholarly sources, was also covered to support debate and argument-focused assignments. To do this, my co-instructor and I modeled and projected our own research approaches in Google Scholar and in a library database, narrating our thought processes related to narrowing topics, selecting keywords, and determining relevance of search results. We also encouraged the students to share with the class their own research tips and tricks based on their previous research experiences.

\section{Discussion}

Not including the research approach modeling described above, the learning activities described in this article were conducted over a 75-minute class period; "Bad Science" readings and blog reflections were assigned as homework before class. The activity could be condensed, if needed, depending on an instructor's particular learning outcomes. "Bad Science" examples could be provided in class, and students could be asked to explore, reflect, and report out reflections individually or in groups. A single example, relevant to course content, could also serve as a starting point for discussions related to information evaluation or science communication in particular.

These activities were selected for honors students who are expected to conduct actual research as part of their college experience. Examples from "Bad Science" are especially 
relevant for students of the social or physical sciences. Nevertheless, instructors of humanities courses could use the same tenets of constructivist theory to develop similar activities by choosing relevant or entirely different examples.

A key recommendation from Project Information Literacy's 2010 report calls for library instruction to focus on higher-order thinking skills, such as interpreting and synthesizing, as opposed to lower-order thinking skills, such as memorizing techniques and rules (Head \& Eisenberg, 2010). Both are essential, but for students to bridge the disconnect between knowing how to evaluate information (e.g., check currency, credentials) and how to apply the knowledge (to select appropriate sources and to understand communication and publication in the digital age) requires higher-order skills. Instructors should not neglect lower-order elements of information literacy instruction but rather present them as purposeful processes instead of decontextualized skills. To do this, students should be held accountable and required to provide evidence that critical thinking took place, by substantiating their search strategy, evaluation, and selection of sources (Head \& Eisenberg).

\section{Conclusion}

This article presents several specific strategies for change in the way librarians and other instructors often teach information literacy. Creating active and reflective learning opportunities grounded in constructivist theory is one way to engage students and incite curiosity in the research and information evaluation processes. When personal context and meaning are established and critical thinking occurs, instructors can increase competency in information literacy and help to broaden students' thinking about information in the digital age.

\section{References}

Burton, V. T., \& Chadwick, S. A. (2000). Investigating the practice of student researchers: Patterns of use and criteria for use of internet and library sources. Computers and Compositions, 17, 309-328. doi: 10.1016/S8755-4615(00)00037-2

Currie, L., Delvier, F., Emde, J., \& Graves, K. (2010). Undergraduate search strategies and evaluation criteria: Searching for credible sources. New Library World, 111(3/4), 113-124. doi: 10.1108/ 03074801011027628

Davis, P. M. (2002). The effect of the web on undergraduate citation behavior: A 2000 update. College $\mathcal{E}$ Research Libraries, 63(1), 53-60.

Goldacre, B. (2010). Bad science. [Column]. The Guardian. Retrieved from http://www.guardian.co.uk/ science/series/badscience

Griffiths, J. R., \& Brophy, P. (2005). Student searching behavior and the web: Use of academic resources and Google. Library Trends, 53, 539-554.

Grimes, D. J., \& Boening, C. H. (2001). Worries with the web: A look at student use of web resources. College \& Research Libraries, 62(1), 11-23.

Head, A. J., \& Eisenberg, M. B. (2010). Truth be told: How college students evaluate and use information in the digital age. A Project Information Literacy Progress Report. The University of Washington. Retrieved from http://projectinfolit.org/pdfs/PIL_Fall2010_Survey_FullReport1.pdf 
Hensley, R. B. (2004). Curiosity and creativity as attributes of information literacy. Reference and User Services Quarterly, 44(1), 31-36.

Huff, D. (1954). How to lie with statistics. New York, NY: Norton.

Johnson, F., Griffiths, J. R., \& Hartley, R. J. (2003). Task dimensions of user evaluations of information retrieval systems. Information Research, 8(4). Retrieved from http://informationr.net/ir/8-4/ paper157.html

Lamon, M. (2003). Constructivist approach. In J. W. Guthrie (Ed.), Encyclopedia of education (2nd ed., pp. 1463-1466). New York, NY: MacMillan Reference USA.

The University of North Carolina Libraries. The scientific publishing cycle. Retrieved from http://www .lib.unc.edu/instruct/biology/biolit/litcycle.html

Van Scoyoc, A. M., \& Cason, C. (2006). The electronic academic library: Undergraduate research behavior in a library without books. portal: Libraries and the Academy, 6(1), 47-58. doi: 10.1353/ pla.2006.0012 